\title{
Distribution and Fishery of the Blue Crab (Callinectes sapidus Rathbun, 1896) in Turkey Based on Local Ecological Knowledge of Fishers
}

\author{
Fikret ÖNDES $^{1^{*} \quad \text { Gökhan GÖKÇE }}{ }^{2}$ \\ ${ }^{1 *}$ Faculty of Fisheries, Izmir Kâtip Çelebi University, Çiğli, Izmir, Turkey \\ ${ }^{2}$ Faculty of Fisheries, Çukurova University, Balcal, Adana, Turkey
}

How to cite: Öndes, F. \& Gökçe, G. (2021). Distribution and Fishery of the Blue Crab (Callinectes sapidus Rathbun, 1896) in Turkey Based on Local Ecological Knowledge of Fishers. J. Anatolian Env. and Anim. Sciences, 6(3), 325-332.

Atıf yapmak için: Öndes, F. \& Gökçe, G. (2021). Balıkçıların Lokal Ekolojik Bilgilerine Göre Mavi Yengecin (Callinectes sapidus Rathbun, 1896) Türkiye'deki Dağılımı ve Balıkçılığı. Anadolu Çev. ve Hay. Dergisi, 6(3), 325-332.

: https://orcid.org/0000-0002-9522-7050 iD : https://orcid.org/0000-0003-1830-0733
*Corresponding author's: Fikret ÖNDES

Faculty of Fisheries, Izmir Kâtip Çelebi University, Çiğli, Izmir, Turkey 凶: fikret.ondes@ikcu.edu.tr

\begin{abstract}
This study provides information on the distribution and ecology of Callinectes sapidus in Turkey, as well as its maximum daily catch in set nets (trammel nets and gillnets), and its commercial fishery in lagoons. Data were collected in 2020 by utilizing a telephone based questionnaire survey. Responses were gathered from fishermen $(n=6)$ who fish in the lagoons and the head or members of fishery cooperatives $(n=104)$ in 28 cities, including the coastal regions of the Mediterranean Sea (Levantine), Aegean Sea, Sea of Marmara and the Black Sea in Turkey. The results showed that $C$. sapidus is commonly distributed along the Levantine and the southern Aegean coasts of Turkey, whilst it is rarely observed in the Sea of Marmara and the Black Sea. Fishermen stated that $C$. sapidus has been seen in the Black Sea for the last decade. The maximum daily catch of blue crab in set nets showed a significant difference in the Levantine and Aegean coasts. The results indicated that the species was mainly produced in the lagoons, whereas many coastal fishermen returned it as discard and $79 \%$ of fishermen emphasized that $C$. sapidus shred the nets and caused an economic loss. Ovigerous females have been observed between March and October and we have discussed related management issues including current fishery season.
\end{abstract}

Keywords: Callinectes sapidus, fisheries management, invasive species, lagoon fishery, local ecological knowledge, marine invasion.

\section{Balıkçıların Lokal Ekolojik Bilgilerine Göre Mavi Yengecin (Callinectes sapidus Rathbun, 1896) Türkiye'deki Dağılımı ve Balıkçılığı}

\author{
*Sorumlu yazar: \\ Fikret ÖNDES \\ İzmir Katip Çelebi Üniversitesi, Su Ürünleri \\ Fakültesi, İzmir, Türkiye \\ 凶: fikret.ondes@ikcu.edu.tr
}

Öz: Bu çalışma, Callinectes sapidus'un Türkiye'deki dağılımı, ekolojisi, uzatma ağlarındaki (fanyalı ve sade ağlar) günlük maksimum avı ve dalyanlardaki ticari balıkçılığı hakkında bilgi sağlamaktadır. Veriler, 2020 yılında yapılan telefon anketleri ile toplanmıştır. Dalyanlarda balıkçılık yapan 6 balıkçı ve Türkiye'nin Akdeniz, Ege, Marmara ve Karadeniz kıyılarını kapsayan toplam 28 ildeki su ürünleri kooperatifi başkanları ya da kooperatif üyeleri (örneklem sayıs1 = 104) anketleri cevaplamıştır. Bulgular, C. sapidus türünün Türkiye'nin Akdeniz ve Güney Ege kıyılarında yaygın olduğunu, Marmara ve Karadeniz kıyılarında ise nadiren gözlemlendiğini göstermiştir. Balıkçılar, C. sapidus'un Karadeniz'de son 10 yıldır görüldügünü belirtmişlerdir. Uzatma ağlarındaki günlük maksimum yengeç avı Akdeniz ve Ege Denizi'nde anlamlı fark göstermiştir. Bulgular, bu türün çoğunlukla dalyanlarda üretilirken, çoğu kıyı balıkçısının 1skarta olarak suya geri bıraktıklarını göstermiş ve kıyı balıkçılarının \%79'u $C$. sapidus türünün ağları parçaladığını ve ekonomik kayba neden olduğunu belirtmiştir. Yumurtalı dişiler Mart ve Ekim ayları arasında gözlemlenmiş olup, mevcut balıkçılık sezonu dâhil olmak üzere yönetim ile ilgili konular değerlendirilmiştir.

Anahtar kelimeler: Balıkçılık yönetimi, Callinectes sapidus, dalyan balıkçılı̆̆ istilacı türler, lokal ekolojik bilgi. 


\section{INTRODUCTION}

Callinectes sapidus Rathbun, 1896, is commonly known as blue crab or Atlantic blue crab and is regionally entitled as "Chesapeake blue crab" around the western Atlantic Ocean and the Gulf of Mexico (Taybi \& Mabrouki, 2020). C. sapidus is one of the 100 worst invasive species and causes damage to nets and target fish species caught by nets (Streftaris \& Zenetos, 2006). This species has been transported to Japanese and European waters via ballast waters of vessels and appeared in the Baltic, North, Mediterranean and Black Seas (Nehring, 2011). Like many other non-indigenous species, the distribution and adaptation of $C$. sapidus in Europe has been influenced by climate change (Nehring et al., 2008).

C. sapidus prefers the sandy and muddy habitats (Hill et al., 1989) and the depths between 0 to $90 \mathrm{~m}$ (Stasolla \& Innocenti, 2014). This species exhibits a migration pattern; after mating females migrate to areas where salinity level is higher (Eggleston et al., 2015). C. sapidus mainly feeds on molluscs, arthropods, fishes and polychaetes, whereas algae species are rarely consumed (Belgrad \& Griffen, 2016; Hines, 2003; Laughlin, 1982; Reichmuth et al., 2009). It was reported that $C$. sapidus can reach a maximum size (carapace width $(\mathrm{CW})$ ) of $20.9 \mathrm{~cm}$ in males and $20.4 \mathrm{~cm}$ in females (FAO, 2020).

Estuaries are major areas for $C$. sapidus populations (Türeli, 1999). Some environmental features including depth and salinity influence the population structure of C. sapidus in these areas (Jivoff et al., 2017). Adult individuals of $C$. sapidus generally mate in these areas then migrate to lower estuaries or offshore waters to spawn and hatch their eggs (Fitz \& Wiegert, 1992). C. sapidus also can be a dominant species in lagoons within relatively short periods. For instance, Kampouris et al., (2019) stated that specimens of $C$. sapidus feed on economically important molluscs, fishes, and crustaceans in the Thermaikos Gulf and Papapouli Lagoon in Greece, and have negative impacts on the Greek national fisheries and aquaculture.

Despite negative effects cited above, it was noticed that blue crab meat has high nutritional quality and various blue crab products have been sold in markets in the US and Europe (Çelik et al., 2004). The global capture of blue crab was reported as $97896 \mathrm{t}$ in 2016 and it was mainly caught around the western Atlantic coast (FAO, 2020). The decrease of $C$. sapidus population in certain regions might be related to overfishing, reduced freshwater inflow into estuaries, and problems in larval recruitment (Weatherall et al., 2018). The main fishing gear used in the capture of blue crab is a crab trap, however they are also caught by trawls and set nets (Hammerschmidt et al.,
1998). In spite of the fact that crab traps are known as selective fishing gears, due to storms, vandalism and vessel propellers, these gears can be lost at sea, which is commonly known as 'ghost fishing' (Anderson \& Alford, 2014; Havens et al., 2008). The minimum landing size of C. sapidus is $127 \mathrm{~mm} \mathrm{CW}$ for hard crabs and harvesting egg-carrying females is prohibited in the Chesapeake Bay (Carver, 2001). On the other hand, blue crab is commercially fished in Turkey and Greece (Gökçe et al., 2007; Mancinelli et al., 2017). Regarding the management of blue crab fishery in Turkey, there are some restrictions including, the minimum landing size (MLS) is $130 \mathrm{~mm}$ $\mathrm{CW}$ and the fishery closed season is between $1^{\text {st }}$ May and $30^{\text {th }}$ September. However, the Ministry of Agriculture and Forestry gives permission rights to its Provincial Directorates; hence the fishermen operating in respective provinces may also get special permissions during closed seasons to operate in lagoons (Anon., 2020a). Regarding recreational fisheries, the MLS is $130 \mathrm{~mm} \mathrm{CW}$ and there is a bag limit which is $1 \mathrm{~kg}$. In contrast to commercial coastal fishers, recreational fishers can fish blue crab throughout the year in Turkey (Anon., 2020b).

It was reported that $C$. sapidus introduced to the northern Aegean Sea between 1935 and 1945 (Artüz, 1990; Enzenroß et al., 1997). Then, the occurrence of $C$. sapidus was reported in different regions of Turkey; Aegean Sea (Kocatas, 1971; Tuncer \& Bilgin, 2008), Mediterranean Sea (Levantine coasts) (Enzenroß et al., 1997), Sea of Marmara (Zaitsev \& Öztürk, 2001) and the Black Sea (Aydın, 2017; Bilgin, 2019; Ceylan, 2020; Yağlığlu et al., 2014). However, previous studies reported this species from one or several localities. The distribution of $C$. sapidus in all Turkish coasts and its fishery have not been evaluated comprehensively yet. In addition, the negative impacts of $C$. sapidus on native species and ecosystem in the Mediterranean has not been sufficiently addressed (Czerniejewski et al., 2020). This study provides information on $C$. sapidus in Turkish waters including; geographical distribution, some bio-ecological characteristics (e.g. egg-carrying period, habitat and depth selectivity), and fishing techniques in lagoons as well as estimated maximum daily catch in the small-scale fisheries (trammel nets and gill nets) in Turkey. There is no doubt that an understanding of the ecological and socio-economic impacts of invasive species in their new ecosystems will help to manage aquatic resources more effectively.

\section{MATERIALS AND METHODS}

Data sampling: The objective of the questionnaire based study was to obtain information on spatial distribution, ecology and fisheries characteristics of C. sapidus in Turkey. The questionnaire mainly consisted 
of the open-ended questions. Telephone based questionnaires were applied in 2020 to commercial fishers (president of fishery cooperatives) who is actively performing small-scale fisheries. If the president of the fishery cooperative did not fish actively, we could apply the questionnaire to other members of the fishery cooperatives. The fishers $(n=104)$ who completed the questionnaire surveys reported using fishing gears including trammel nets and gillnets to catch many different target species. The data were collected from 28 cities including 110 fishing grounds, in order to reliably represent the coastal regions of Turkey (Figure 1a). The questionnaire provided information on; i) some demographic characteristics of fishers (age, gender, fishing experience), ii) bio-ecological characteristics of $C$. sapidus (e.g. distribution, depth and habitat selectivity, temporal trends in abundance, estimation of spawning and molting periods), and iii) fishery characteristics (e.g. determination of the fishing gears types caught blue crabs, estimated maximum daily catch in 2019). If C. sapidus did not emerge in the fishers' fishing grounds, they were exempt from answering some questions. Additionally, another questionnaire was applied to fishers $(n=6)$ who produce blue crabs in lagoons with barrier traps, wire pots and fyke nets. This second questionnaire included identical questions to the first one, with the addition of questions related to the lagoon fishery.
Data analysis: The SPSS (version 20.0) was used for the statistical analyses in this study. A Mann Whitney $\mathrm{U}$ test was utilized to ascertain whether the maximum daily catch of blue crab shows a difference in Levantine and Aegean or not.

\section{RESULTS}

The age of fishers who participated in the questionnaire survey ranged between 25 and 70 with a mean value of $49 \pm 9$ years. All of them were male and their fishing experience ranged between 7 and 56 years, while the mean fishing experience was $32 \pm 11$ years.

Distribution and some ecological characteristics of Callinectes sapidus: Concerning the occurrence of $C$. sapidus, $100 \%, 72 \%$ and $46 \%$ of fishermen who fish around the Levantine coasts, Aegean coasts and Sea of Marmara (excluding Çanakkale Strait), respectively reported that they detected this species at least once in their nets. While only $17 \%$ of fishermen have encountered with C. sapidus in the Black Sea to date. In other words, $C$. sapidus is commonly distributed around the southern and western coasts of Turkey, whereas it has rarely been observed in the Sea of Marmara and the Black Sea (Figure $1 b)$.

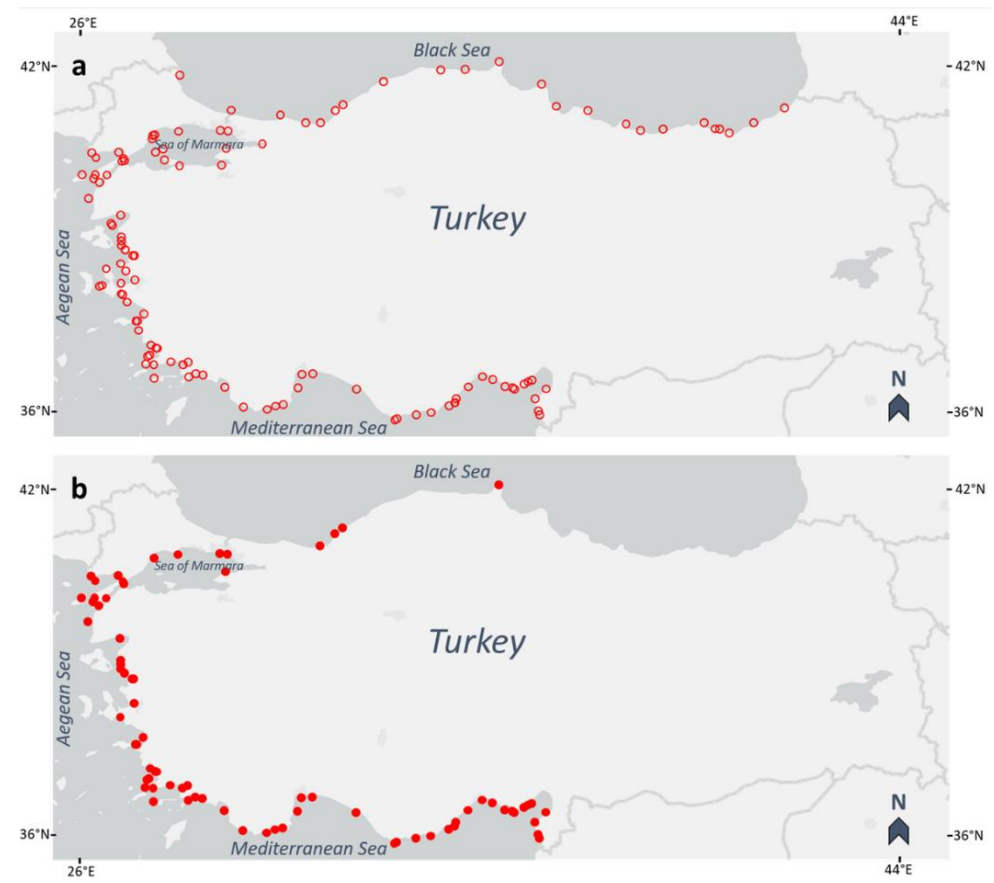

Figure 1. a) Spatial distribution of respondents, b) Spatial distribution of the recorded observations of Callinectes sapidus in Turkey.

In order to evaluate whether this distribution has changed over the years or not, fishermen with more than 20 years of experience were asked; "how long have you seen C. sapidus in your fishing grounds?" The answers related to this question proved that many fishermen around the Levantine coast of Turkey have seen this species for more than 20 years, whereas this species just started to be encountered in the Black Sea over the last several years
(Table 1). Concerning the current status of $C$. sapidus population, $73 \%$ of fishermen who fish around the Levantine coasts considered that its population has had stable characteristics for the last 10 years, whereas $44 \%$ of fishermen who fish around the Aegean Sea reported an increased trend (Table 1). Meanwhile, a decreasing population was mainly detected by fishermen who fish around the northern Aegean Coast. 
Table 1. Fishers' observations on the occurrence and population trend of Callinectes sapidus in Turkey.

\begin{tabular}{|c|c|c|c|c|c|c|}
\hline \multirow[b]{2}{*}{$\begin{array}{l}\text { Fishing } \\
\text { ground }\end{array}$} & \multicolumn{3}{|c|}{$\begin{array}{l}\text { How long have you seen } \\
\text { C. sapidus? }\end{array}$} & \multicolumn{3}{|c|}{$\begin{array}{l}\begin{array}{l}\text { Population trend for the last } 10 \\
\text { years }\end{array}\end{array}$} \\
\hline & $\begin{array}{l}<10 \\
\text { years } \\
(\%)\end{array}$ & $\begin{array}{l}10-20 \\
\text { years } \\
(\%)\end{array}$ & $\begin{array}{l}>20 \\
\text { years } \\
(\%)\end{array}$ & $\begin{array}{l}\text { Decrease } \\
(\%)\end{array}$ & $\begin{array}{l}\text { Increase } \\
(\%)\end{array}$ & $\begin{array}{l}\text { Stable } \\
(\%)\end{array}$ \\
\hline Levantine & 0 & 8 & 92 & 18 & 9 & 73 \\
\hline $\begin{array}{l}\text { Aegean } \\
\text { Sea }\end{array}$ & 20 & 64 & 16 & 31 & 44 & 25 \\
\hline $\begin{array}{l}\text { Sea of } \\
\text { Marmara }\end{array}$ & 90 & 10 & 0 & NA & NA & NA \\
\hline Black Sea & 100 & 0 & 0 & NA & NA & NA \\
\hline
\end{tabular}

The main habitats of $C$. sapidus were determined as muddy and sandy sediments by $94 \%$ of fishermen. It was reported that this species was also rarely found in vegetated and rocky habitats. Based on commercial fishermen's responses who mainly fish at depths less than $200 \mathrm{~m}$, C. sapidus was distributed in depths between $0.5 \mathrm{~m}$ to $40 \mathrm{~m}$ and was mainly caught in depths between $0.5 \mathrm{~m}$ to $10 \mathrm{~m}$ around Turkish coasts. In this study, ovigerous females were reported by trammel netters and gill netters from Levantine and Aegean coasts for the period between March and October, and March and September, respectively. Similarly, egg-carrying crabs were reported from lagoons between May and September. Even though we asked the question on molting periods of male and female crabs to fishermen, they could not clearly identify the molting periods. Furthermore, only a few fishermen who fished in the lagoons identified molting period as between May and August. However, they could not identify aforementioned period separately for male and female crabs.

\section{Commercial fisheries}

Coastal fishery: The results showed that $C$. sapidus was mainly caught by trammel nets and gillnets as a by-catch species. No fishermen identified the blue crab as the main target species. Fishermen who used these fishing gears noted that their main target species are red mullet, striped red mullet, shrimp, common sole, grey mullet, sea bass, blue fish and Atlantic bonito. Fishermen reported that $C$. sapidus was also rarely caught by encircling nets. In this study, a total of 9 fishermen indicated that they sold caught crabs, whereas others preferred to return them to the sea or, in rare cases, consume them. It was noticed that both male and female crabs were sold at the fishery cooperatives. The prices of C. sapidus ranged from 5 to 30 Turkish Lira (TL)/kg (0.56$3.36 € / \mathrm{kg}$ ) in 2020 . There was a statistically significant difference in the reported maximum daily catch of $C$. sapidus between the Levantine and Aegean Sea $(\mathrm{U}=$ $48,000, \mathrm{P}=0.002$ ). The higher daily catch values were found around the Levantine coasts (Figure 2).

In this study, $79 \%$ of fishermen, used trammel and gill nets, expressed that $C$. sapidus causes damage to their fishing gears (e.g. shred the nets) and results in economic loss. Additionally, only $27 \%$ of fishermen reported that $C$. sapidus has a negative impact on the aquatic ecosystems. Regarding blue crab fishery management in Turkey, all fishermen who sell blue crabs had information about the fishing season.

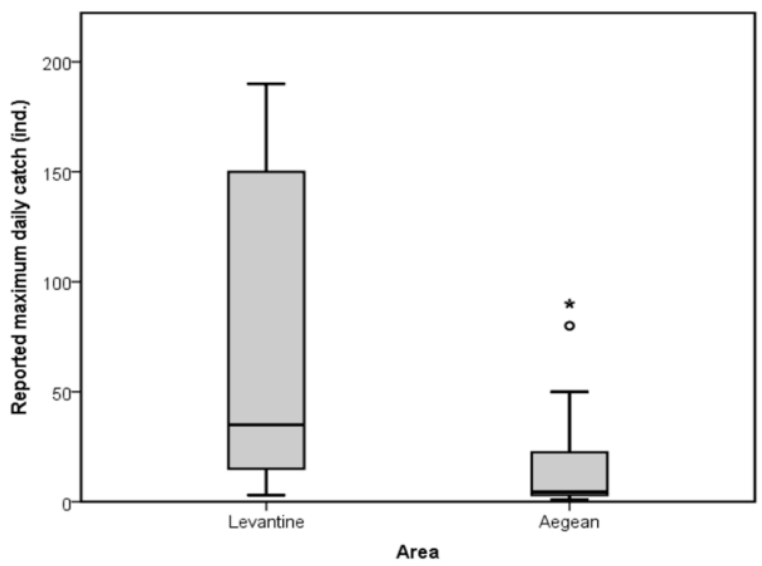

Figure 2. Reported maximum daily catch of Callinectes sapidus in set nets (combined data from trammel and gill nets) in Levantine coasts and Aegean coasts of Turkey in 2019.

Lagoon fishery: Blue crab fishery has been performed actively in several lagoons in Turkey. In addition to blue crab, gilthead seabream, European seabass, mullet, and European eel were stated by fishermen as the main target species in these lagoons. The blue crab has been fished at depths ranging from 0.5 to $2 \mathrm{~m}$. Fishermen noticed that the main habitats of these lagoons were reported as muddy and sandy. In these lagoons, crabs have been caught mainly by barrier traps (Figure 3a). Scoop nets have been used to capture blue crabs in these barrier traps. In addition, other traps such as pots and fyke nets have been also used for catch. The pots used were mainly rectangular in shape with hexagonal wire mesh (Figure 3b) and the commonly used mesh bar size varied from 20 to $25 \mathrm{~mm}$. Fish species including sardine, carp, mullet, smelt and also chicken were used as bait in traps. $C$. sapidus has been landed throughout the year in lagoons. In particular, the highest production period for blue crab was reported as between May and August. The maximum daily blue crab catch in lagoons was between 60 and $600 \mathrm{~kg}$. Although the estimated annual production in these lagoons was between 1 and $15 \mathrm{t}$ due to limited demand, fishermen estimated the stock size of blue crabs can reach up to $150 \mathrm{t}$ in one lagoon in the eastern Mediterranean. Fishermen notified that the mean $\mathrm{CW}$ of sold crabs ranged from 13 to $16 \mathrm{~cm}$ in lagoons and all fishermen had information on the minimum landing size. Fishermen acknowledged that the ovigerous (sponge) was not sold from in the lagoon fishery. Both male and female crabs were exported live, however some fishermen noted that females were more resistant in transportation. Fishermen declared that these crabs were exported to China and the Netherlands and also some of them were sold at domestic markets and restaurants in Adana, Antalya, 
Muğla and İstanbul. The prices of exported blue crabs ranged from 7 to $9 € / \mathrm{kg}$, while the prices of crabs sold to domestic markets ranged from 0.34 to $2.24 € / \mathrm{kg}$ in 2020 . All fishermen reported that blue crab causes damage to fishing nets and half of them believed blue crab also damaged other species in lagoons.

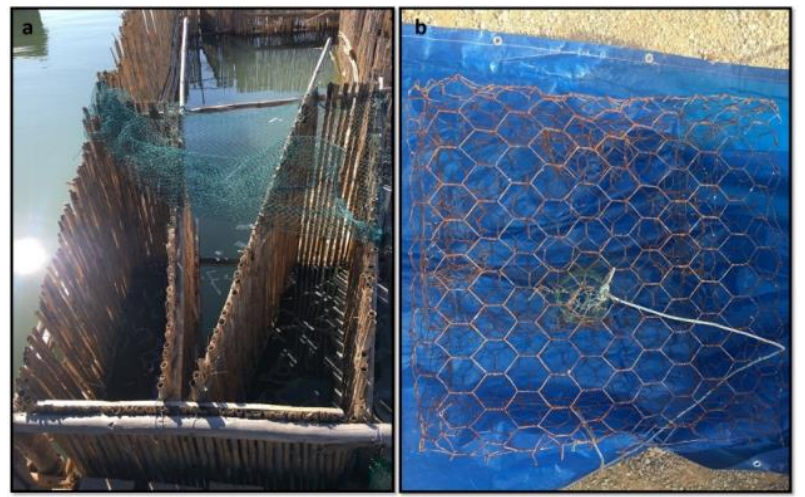

Figure 3. Fishing gears used in the lagoons; a) barrier traps, b) rectangular hexagonal mesh wire trap (photos by Gökhan Gökçe).

\section{DISCUSSION}

The occurrence of $C$. sapidus in Europe (Atlantic coast of France) has been detected since the earlier periods of the 1900's (Czerniejewski et al., 2020). The first record of $C$. sapidus in the Mediterranean was given by Giordani Soika, (1951). Due to the ballast waters, the species expanded rapidly (Mancinelli et al., 2017; Öztürk et al., 2020). C. sapidus was also reported from the Black Sea (Bulgurkov, 1968) and the northern Aegean Sea (Artüz, 1990). Then it spread to the Aegean and Mediterranean coasts of Turkey (Enzenroß et al., 1997). New records of C. sapidus found in different locations of Turkish waters were reported by Turkish Scientists (Aydın, 2017; Bilgin, 2019; Ceylan, 2020; Kocataş, 1971; Tuncer \& Bilgin, 2008; Yağlığlu et al., 2014). The present study provided the most comprehensive information about the distribution of $C$. sapidus in Turkey. It should be noted that local ecological knowledge (LEK) is a valuable source to evaluate the distribution of invasive species in large geographical areas. Our results highlighted that the population size of $C$. sapidus was high throughout the Levantine coasts and some areas of the Aegean Sea, whereas this species was rarely observed by fishermen in the Sea of Marmara and the Black Sea (Figure 1b). This species was also recorded in some sites of the eastern Black Sea (Trabzon and Ordu-Fatsa) according to the previous studies (Bilgin, 2019; Ceylan, 2020).

The mating success and fecundity may be considered as important indicators for the adaptation of non-native species to new environments. C. sapidus exhibits high fecundity; ovigerous specimens can produce 8 million eggs per spawn in Chesapeake Bay (Prager et al.,
1990). Previous studies showed that the Mediterranean population of $C$. sapidus also represented relatively high fecundity; which ranged from 244,000 to 7 million eggs in İskenderun, Turkey (Türeli, 1999) and from 742,652 to 7,359,642 eggs in Köyceğiz Lagoon, Turkey (Gülşahin, 2007). The success of reproduction and distribution of $C$. sapidus were dependent on water temperature (Nehring, 2011) and the optimal spawning conditions were noted as $19-22{ }^{\circ} \mathrm{C}$ and $0-8 \mathrm{hr}$ of darkness (Bembe et al., 2017). Thus, water temperature condition is proper for the reproduction and growth of $C$. sapidus in the Levantine coasts of Turkey, and this situation supports the highest catch that can be considered as relative abundance has been found in that region in the present study. However, due to the increasing trend of water temperature in the Sea of Marmara and the Black Sea, the recorded exotic species number has increased over the last years (Erdogan Saglam et al., 2010; Öztürk et al., 2020; Turan et al., 2018). Hence, the abundance of both the blue crab and other exotic species may show a dramatic increase in the Sea of Marmara and the Black Sea ecosystems in the future.

The present study revealed that, based on many fishermen's perspective, the population of $C$. sapidus was stable for the last 10 years around the Levantine coasts, whilst increase and decrease trends were reported from some fishing grounds of the Aegean Sea. Similarly, Cerri et al., (2020) collected data from recreational fishermen in Italy and reported that many fishers evaluated the population trend as "stable or fluctuating" $(43.5 \%)$ or "increasing" (40.3\%). On the other hand, the distribution area of $C$. sapidus widened; for instance, Mancinelli et al., (2017) noted that the number of blue crab records increased in the Mediterranean Sea and southern European waters in the last years.

Some invasive species have strong negative ecological and economic effects and cause damage to fishing gears (Galanidi et al., 2018). In the present study, many trammel netters and gillnetters $(79 \%)$ reported that C. sapidus shredded the nets and caused significant economic loss in some fishing grounds, and $27 \%$ of coastal fishermen highlighted that this species has a negative influence on aquatic ecosystems. There is no doubt that the impact level of exotic species on fisheries depends on their abundance. For example, Cerri et al., (2020) evaluated the potential environmental consequences of $C$. sapidus in Italy, Croatia and Montenegro and many of the questionnaire survey participants did not have clear ideas about the environmental consequences, and few respondents believed $C$. sapidus has a negative effect on the environment and fishery. Besides, the economic impacts of $C$. sapidus in the small-scale fishery should be studied as a further study. However, it should be noted that not only blue crab but also other aquatic animals such as 
pufferfishes, dolphins and sea turtles can cause damage to nets, such as shredding.

Our results showed that although some fishermen caught blue crab by trammel nets and gillnets around the Levantine and southern Aegean coast, due to its relatively low price compared with native species (e.g. red mullet, striped mullet, shrimp) and limited demand, this species has been mainly considered as a 'by-catch species' depending on catch rate in the coastal fishery. Hence, there is no standardized fishing gear and mesh size for the fishery of blue crab in Turkey. The size selectivity of traps and escape rates of $C$. sapidus in Turkey was evaluated in previous studies (Atar et al., 2002; Gökçe et al., 2007; Özdemir et al., 2015). For instance, Atar et al., (2002) compared the catch per unit effort (CPUE) of traps and hoop nets and noted that the mean CPUE of hoop nets was significantly higher than the mean CPUE of traps. Based on a laboratory study Gökçe et al., (2007) compared the escape success of $C$. sapidus in traps using three different square mesh barriers $(35,40$, and $45 \mathrm{~mm}$ bar length). They reported that L50 for the 35, 40, and $45 \mathrm{~mm}$ bar length (mean \pm s.e.) was $8.09 \pm 0.12,9.32 \pm 0.09$, and $10.56 \pm$ 0.11 , respectively. Similarly, Özdemir et al., (2015) investigated the size selectivity in traps using four different mesh sizes (30, 35, 40, 45 and $50 \mathrm{~mm}$ ) and they ascertained that using a $50 \mathrm{~mm}$ square mesh demonstrated high selectivity with a high escape rate of immature individuals.

The results of the present study demonstrated that the production of blue crab is mainly provided by lagoon fishery in Turkey. According to previous studies, the exploitation and management of $C$. sapidus in Turkey started in the early 1990's (Öztürk et al., 2020; Zaitsev \& Öztürk, 2001). The present study also noted that the annual production of $C$. sapidus in one lagoon can reach up to 15 t. The abundance of blue crabs and its interactions with other species in lagoons should be studied in the future.

The MLS of C. sapidus increased from 8 to $13 \mathrm{~cm}$ CW in Turkey (Anon., 2020a; Anon., 2020b; Gökçe et al., 2007). The size onset of sexual maturity (SOM) of $C$. sapidus in the south coast of Turkey was determined by Türeli (1999) and the aforementioned study reported that females mature at $6.05 \mathrm{~cm}$ carapace length (CL), whereas males mature at $4.48 \mathrm{~cm}$ CL. It was reported that SOM of crabs show a difference depending on geographical areas (Gökçe et al., 2007; Türeli, 1999). Thus, to understand whether the current MLS is available or not more observations related to the SOM in the different sites of Turkey should be performed.

Another management measure related to the blue crab is fishery closed season for coastal fishery in Turkey. The current closed season of blue crab fishery (between 1st May and 30th September) spans across a relatively large period (Anon., 2020a) but according to our results ovigerous crabs can be captured from March to October. In addition, Türeli (1999) investigated the reproduction of $C$. sapidus in Yumurtalik (the southeastern coasts of Turkey) and noted that sponged females were observed from March to end of September (Table 2). Similarly, the ovigerous individuals were observed from May to October in Köyceğiz Lagoon, Turkey (Gülşahin \& Erdem, 2009). On the other hand, the landing of ovigerous and soft crabs has not been prohibited in Turkey yet and the fishermen can fish blue crab with special permit throughout the year in lagoons. To develop the effective management tools, a priority should be given to investigate the ecological impacts of this invasive species on native species and the economic loss caused by $C$. sapidus in the small-scale fisheries.

Table 2. Temporal distribution of the ovigerous individuals of Callinectes sapidus and its current fishery closed season in Turkey.

\begin{tabular}{|c|c|c|c|c|c|c|c|c|c|c|c|c|}
\hline \multicolumn{13}{|l|}{ Geographical area (Study) } \\
\hline Yumurtalık (LE) (Türeli, 1999) & & & & & & & & & & & & \\
\hline Köyceğiz(AS) (Gülşahin \& Erc & & & & & & & & & & & & \\
\hline Aegean Sea (This Study, 2021) & & & & & & & & & & & & \\
\hline Levantine (This Study, 2021) & & & & & & & & & & & & \\
\hline Current fishery closed season & & & & & & & & & & & & \\
\hline
\end{tabular}

Consequently, the knowledge on spatial distribution of $C$. sapidus in Turkey has expanded over recent years. Due to the decline in stocks of native species in Mediterranean, some exotic species may be considered as an alternative food source for this region in the future. The blue crab is one example that started to be an economically important crustacean species of Turkey's lagoon fishery, whereas it causes monetary loss in gillnet and trammel net fishery and relatively few fishermen caught it as a secondary target species. More studies are required to reveal ecological and economic impacts of $C$. sapidus on the Mediterranean ecosystem.

\section{ACKNOWLEDGMENTS}

We would like to thank all participants of the questionnaire study. We also thank to Mrs Holly Aymelek and Dr Murat Aymelek for the language editing.

\section{REFERENCES}

Anderson, J.A. \& Alford, A.B. (2014). Ghost fishing activity in derelict blue crab traps in Louisiana. Marine Pollution Bulletin, 79, 261-267. DOI: 10.1016/j.marpolbul.2013.12.002 
Artüz, I. (1990). Mavi yengecin serüvenleri. Cumhuriyet Bilim Teknik, 148, 6.

Atar, H.H., Ölmez, M., Bekcan, S. \& Seçer, S. (2002). Comparison of three different traps for catching blue crab (Callinectes sapidus Rathbun 1896) in Beymelek Lagoon. Turkish Journal of Veterinary and Animal Sciences, 26, 1145-1150.

Aydın, M. (2017). First record of Blue Crab Callinectes sapidus (Rathbun 1896) from the Middle Black Sea Coast. Turkish Journal of Maritime and Marine Sciences, 3(2), 121-124.

Belgrad, B.A. \& Griffen, B.D. (2016). The influence of diet composition on fitness of the blue crab, Callinectes sapidus. PloS one, 11(1), e0145481. DOI: 10.1371/journal.pone.0145481

Bembe, S., Liang, D. \& Chung, J.S. (2017). Optimal temperature and photoperiod for the spawning of blue crab, Callinectes sapidus, in captivity. Aquaculture Research, 48, 5498-5505. DOI: 10.1111/are.13366

Bilgin, S. (2019). Review: An update list of crab species (Crustacea: Decapoda: Brachyura) with exotic crabs in the Black Sea Fauna. Journal of Anatolian Environmental and Animal Sciences, 4, 211-215. DOI: 10.35229/jaes.566520

Bulgurkov, K. (1968). Callinectes sapidus Rathbum (Crustacea-Decapoda) in the Black Sea. Izvnauchnoizsl Inst Rib Stop Okeanogr, 9, 33-36.

Carver, A.M. (2001). Selective fishing pressure on large male blue crabs negatively affects male size, sex ratio, and population reproductive potential in the upper Chesapeake Bay. M.S. Thesis. Department of Marine, Earth and Atmospheric Sciences, North Carolina State University, Raleigh. 38 p.

Cerri, J., Chiesa, S., Bolognini, L., Mancinelli, G., Grati, F., Dragičević, B., Dulčic, J. \& Azzurro, E. (2020). Using online questionnaires to assess marine bio-invasions: A demonstration with recreational fishers and the Atlantic blue crab Callinectes sapidus (Rathbun, 1986) along three Mediterranean countries. Marine Pollution Bulletin, 156, $111209 . \quad$ DOI: 10.1016/j.marpolbul.2020.111209

Ceylan, Y. (2020). The blue crab (Callinectes sapidus, Rathbun, 1896) is spreading in the Southern Coast of the Black Sea. Marine Science and Technology Bulletin, 9, 168-172. DOI: 10.33714/masteb.753593

Czerniejewski, P., Kasowska, N., Linowska, A. \& Rybczyk, A. (2020). A new record of the invasive blue crab (Callinectes sapidus Rathbun, 1896) and his parasite from the Baltic basin. Oceanologia, $\quad 62, \quad 111-115 . \quad$ DOI: 10.1016/j.oceano.2019.06.004

Çelik, M., Türeli, C., Çelik, M., Yanar, Y., Erdem, Ü. \& Küçükgülmez, A. (2004). Fatty acid composition of the blue crab (Callinectes sapidus Rathbun, $1896)$ in the north eastern Mediterranean. Food chemistry, $\quad 88, \quad 271-273 . \quad$ DOI: 10.1016/j.foodchem.2004.01.038
Eggleston, D.B., Millstein, E. \& Plaia, G. (2015). Timing and route of migration of mature female blue crabs in a tidal estuary. Biology letters, 11, 20140936. DOI: 10.1098/rsbl.2014.0936

Enzenroß, R., Enzenroß, L. \& Bingel, F. (1997). Occurrence of blue crab, Callinectes sapidus (Rathbun, 1896) (Crustacea, Brachyura) on the Turkish Mediterranean and the adjacent Aegean coast and its size distribution in the bay of Iskenderun. Turkish Journal of Zoology, 21, 113122.

Erdogan Saglam, N., Duzgunes, E., Ogut, H. \& Kasapoglu, N. (2010). Introduced species and their impacts in the Black Sea. In CIESM Congress. Venice, Italy.

FAO. (2020). http://www.fao.org/fishery/species/2632/en. Access date: 29.12.2020.

Fitz, H.C. \& Wiegert, R. G. (1992). Local population dynamics of estuarine blue crabs: abundance, recruitment and loss. Marine Ecology Progress Series, 87, 23-40.

Galanidi, M., Zenetos, A. \& Bacher, S. (2018). Assessing the socio-economic impacts of priority marine invasive fishes in the Mediterranean with the newly proposed SEICAT methodology. Mediterranean Marine Science, 19, 107-123. DOI: $10.12681 / \mathrm{mms} .15940$

Giordani Soika, A. (1951). Il Neptunus pelagicus (L.) nell'alto Adriatico. Natura, 42, 18-20.

Gökçe, G., Çekiç, M., Metin., C. \& Özbilgin, H. (2007). Size selectivity of square mesh barriers for Callinectes sapidus (Rathbun, 1896) (Brachyura, Portunidae). Crustaceana, 80, 277-284.

Gülşahin, A. (2007). Köyceğiz Gölü dalyan kanallarında bulunan mavi yengeç (Callinectes sapidus Rathbun, 1896)'in bazı biyolojik özellikleri. MSc Thesis, Muğla University, $57 \mathrm{p}$.

Gülșahin, A. \& Erdem, M. (2009). Length-weight relationships in blue crab, Callinectes sapidus (Rathbun, 1896) in Köycegiz Dalyan Lagoon Area-Turkey. Journal of Fisheries Sciences.com, 3, 24-31.

Hammerschmidt, P., Wagner, T. \& Lewis, G. (1998). Status and trends in the Texas blue crab (Callinectes sapidus) fishery. Journal of Shellfish Research, 17, 405-412.

Havens, K.J., Bilkovic, D.M., Stanhope, D., Angstadt, K. \& Hershner, C. (2008). The effects of derelict blue crab traps on marine organisms in the lower York River, Virginia. North American Journal of Fisheries Management, 28, 1194-1200. DOI: 10.1577/M07-014.1

Hill, J., Fowler, D.L., Avyle, M.V. (1989). Species profiles: Life histories and environmental requirements of coastal fishes and invertebrates (Mid-Atlantic) - Blue crab. U.S. Fish Wildl. Serv. Biol. Rep. 82(11.100). U.S. Army Corps of Engineers, TR EL-82-4. 18 pp., Vicksburg.

Hines, A.H. (2003). Ecology of juvenile and adult blue crabs: summary of discussion of research themes 
and directions. Bulletin of Marine Science, 72, 423-433.

Jivoff, P.R., Smith, J.M., Sodi, V. L., VanMorter, S.M., Faugno, K.M., Werda, A.L. \& Shaw, M.J. (2017). Population structure of adult blue crabs, Callinectes sapidus, in relation to physical characteristics in Barnegat Bay, New Jersey. Estuaries and Coasts, 40, 235-250. DOI: 10.1007/s12237-016-0127-8

Kampouris, T.E., Porter, J.S. \& Sanderson, W.G. (2019). Callinectes sapidus Rathbun, 1896 (Brachyura: Portunidae): An assessment on its diet and foraging behaviour, Thermaikos Gulf, NW Aegean Sea, Greece: Evidence for ecological and economic impacts. Crustacean Research, 48, 23-37. DOI: 10.18353/crustacea.48.0_23

Kocatas, A. (1971). Izmir Körfezi ve civari yengeçlerinin" Brachyura" taksonomi ve ekolojisi üzerine arastirmalar. Scientific Reports of the Faculty of Science Ege University, 121, 1-77.

Laughlin, R.A. (1982). Feeding habits of the blue crab, Callinectes sapidus Rathbun, in the Apalachicola estuary, Florida. Bulletin of Marine Science, 32, 807-822.

Mancinelli, G., Chainho, P., Cilenti, L., Falco, S., Kapiris, K., Katselis, G. \& Ribeiro, F. (2017). The Atlantic blue crab Callinectes sapidus in southern European coastal waters: Distribution, impact and prospective invasion management strategies. Marine Pollution Bulletin, 119, 5-11. DOI: 10.1016/j.marpolbul.2017.02.050

Nehring, S., Speckels, G. \& Albersmeyer, J. (2008). The American blue crab Callinectes sapidus Rathbun on the German North Sea coast: Status quo and further perspectives. Senckenbergiana maritima, 38(1), 39-44.

Nehring, S. (2011). Invasion history and success of the American blue crab Callinectes sapidus in European and adjacent waters. In the wrong placealien marine crustaceans: distribution, biology and impacts (pp. 607-624). Springer, Dordrecht.

Özdemir, S., Gökçe, G. \& Cekic, M. (2015). Determination of size selectivity of traps for blue crab (Callinectes sapidus Rathbun, 1896) in the Mediterranean Sea. Journal of Agricultural Sciences, 21, 256-261. DOI: 10.1501/Tarimbil_0000001327

Öztürk, R.Ç., Terzi, Y., Feyzioğlu, A.M., Şahin, A. \& Aydın, M. (2020). Genetic characterization of the invasive blue crab, Callinectes sapidus (Rathbun, 1896), in the Black Sea. Regional Studies in Marine Science, 39, 101412. DOI: 10.1016/j.rsma.2020.101412

Prager, M.H., Mc Conaugha, J.R., Jones, C.M. \& Geer, P.J. (1990). Fecundity of blue crab, Callinectes sapidus, in Chesapeake Bay: biological, statistical and management considerations. Bulletin of Marine Science, 46, 170-179.

Reichmuth, J.M., Roudez, R., Glover, T. \& Weis, J.S. (2009). Differences in prey capture behavior in populations of blue crab (Callinectes sapidus
Rathbun) from contaminated and clean estuaries in New Jersey. Estuaries and Coasts, 32, 298-308. DOI: $10.1007 / \mathrm{s} 12237-008-9130-\mathrm{Z}$

Stasolla, G. \& Innocenti, G. (2014). New records of the invasive crabs Callinectes sapidus Rathbun, 1896 and Percnon gibbesi (H. Milne Edwards, 1853) along the Italian coasts. BioInvasions Records, 3, 39-43. DOI: 10.3391/bir.2014.3.1.07

Streftaris, N. \& Zenetos, A. (2006). Alien marine species in the Mediterranean-the 100 'Worst Invasives' and their impact. Mediterranean Marine Science, 7(1), 87-118. DOI: $10.12681 / \mathrm{mms} .180$

Taybi, A.F. \& Mabrouki, Y. (2020). The American blue crab Callinectes sapidus Rathbun, 1896 (Crustacea: Decapoda: Portunidae) is rapidly expanding through the Mediterranean Coast of Morocco. Thalassas: An International Journal of Marine Sciences, 36, 267-271. DOI: 10.1007/s41208-020-00204-0

Tuncer, S. \& Bilgin, S. (2008). First record of Callinectes sapidus Rathbun, 1896 (Crustacea: Decapoda: Brachyura) in the Dardanelles, Canakkale, Turkey. Aquatic Invasions, 3(4), 469. DOI: 10.3391/ai.2008.3.4.19

Turan, C., Gürlek, M., Başusta, N., Ali, U., Doğdu, S.A. \& Karan, S. (2018). A checklist of the nonindigenous fishes in Turkish marine waters. Natural and Engineering Sciences, 3, 333-358. DOI: $10.28978 /$ nesciences.468995

Türeli, C. (1999). Aspects of the biology of blue crab (Callinectes sapidus Rathbun, 1896) in İskenderun Bay (Turkey): 1-161. (Ph.D. Thesis, Department of Fisheries, Institute of Natural and Applied Sciences, University of Çukurova). [In Turkish, with English abstract.]

Yağlığlu, D., Turan, C. \& Öğreden, T. (2014). First record of blue crab Callinectes sapidus (Rathbun 1896) (Crustacea, Brachyura, Portunidae) from the Turkish Black Sea coast. Journal of Black Sea/Mediterranean Environment, 20, 13-17.

Weatherall, T.F., Scheef, L.P. \& Buskey, E.J. (2018). Spatial and temporal settlement patterns of blue crab (Callinectes sapidus and Callinectes similis) megalopae in a drought-prone Texas estuary. Estuarine, Coastal and Shelf Science, 214, 89-97. DOI: 10.1016/j.ecss.2018.09.017

Zaitsev, Y. \& Öztürk, B. (2001). Exotic species in the Aegean, Marmara, Black, Azov and Caspian Seas. Turkish Marine Research Foundation, Istanbul, $267 \mathrm{pp}$.

Anon. (2020a). 5/1 Numaralı ticari amaçlı su ürünleri avcılığının düzenlenmesi hakkında tebliğ (tebliğ no: 2020/20) [Communiqué on the regulation of commercial fisheries No. 5/1 (Communiqué No. 2020/20).] [In Turkish.]

Anon. (2020b). 5/2 Numaralı amatör amaçlı su ürünleri avcılığının düzenlenmesi hakkında tebliğ (tebliğ no: 2020/21) [Communiqué on the regulation of recreational fisheries No. 5/2 (Communiqué No. 2020/21).] [In Turkish.] 